\title{
Irrigation and Nitrogen Management of Artichoke: Yield, Head Quality, and Phenolic Content
}

\author{
Togo Shinohara, Shinsuke Agehara, Kil Sun Yoo, \\ and Daniel I. Leskovar ${ }^{1,2}$ \\ Texas AgriLife Research, Vegetable and Fruit Improvement Center, Department \\ of Horticultural Sciences, Texas A\&M University, 1619 Garner Field Road, \\ Uvalde, TX 78801
}

Additional index words. Cynara scolymus, chlorogenic acid, cynarin, crop evapotranspiration, deficit irrigation, soil nitrates, stomatal conductance

\begin{abstract}
Globe artichoke [Cynara cardunculus L. var. scolymus (L.) Fiori] has been recently introduced as a specialty crop in southwest Texas. Marketable yield, yield components, quality, and phenolic compounds of artichoke heads were investigated in response to three irrigation $[50 \%, 75 \%$, and $100 \%$ crop evapotranspiration (ETc)] regimes and four nitrogen $\left(0\right.$ to $10,60,120$, and $180 \mathrm{~kg} \cdot \mathrm{ha}^{-1}$ ) rates under subsurface drip irrigation. Field experiments were conducted over three seasons $(2005-2006,2006-2007$, and 2007-2008) at Uvalde, TX. Irrigation was more effective than nitrogen $(N)$ rates to optimize crop yield and head quality. Marketable yields significantly increased at $100 \%$ ETc compared with $75 \%$ and $50 \%$ ETc, whereas a $20 \%$ to $35 \%$ yield reduction occurred at $50 \%$ ETc across seasons. This yield reduction was associated with a decrease in both number of marketable heads and head weight and with reductions in plant physiological responses as measured in the last season. The lack of yield responses to $\mathrm{N}$ rates was in part the result of high pre-plant soil $\mathrm{NO}_{3}-\mathrm{N}$ and $\mathrm{NH}_{4}-\mathrm{N}$ levels. Total phenolics and chlorogenic acid of artichoke heads increased as the harvesting season progressed and were highest at $50 \%$ ETc during mid- and late harvests in one season. Based on these results, we estimate that under these environmental conditions, $\approx 700 \mathrm{~mm}$ (for a bare soil system) of water inputs and $120 \mathrm{~kg} \cdot \mathrm{ha}^{-1}$ or less of $\mathrm{N}$ (rate depending on soil available $\mathrm{N}$ ) appear sufficient to obtain high marketable yields, superior size, and nutritional head quality of artichokes.
\end{abstract}

Globe artichoke [Cynara cardunculus L. var. scolymus (L.) Fiori] is a thistle-like perennial plant that belongs to the Asteraceae family. In commercial production, plants are usually grown from 1 to 4 years and occasionally up to 10 years (Ryder et al., 1983; Schrader and Mayberry, 1997; Tesi et al., 2004). The main marketable part of artichoke is the immature flower buds or capitulum, known as the head. The artichoke plant has a deep taproot, up to $120 \mathrm{~cm}$, and the canopy can grow 60 to $120 \mathrm{~cm}$ high with a rosette of large leaves and blanched flowering stems (Sims et al., 1977). The plants require a low temperature followed by long days for head formation and stem elongation (Basnizky, 1985).

In the United States, fresh artichoke is known as a specialty crop, which is sold at

Received for publication 11 Aug. 2010. Accepted for publication 30 Nov. 2010.

This research was funded in part by the Texas Water Development Board, USDA-CSREES Designing Foods for Health \#2005-34402-16401, and USDA-Rio Grande Basin Initiative \#2005-34461-15661.

We thank Juan Gonzalez, Juan Esquivel, Floyd Hood, and Carrie Hensarling for their assistance in field and laboratory procedures and to Condor Seeds for providing seed materials.

'Professor.

${ }^{2}$ To whom reprint requests should be addressed; e-maild-leskovar@tamu.edu. a retail price of $\$ 1.00$ per head and up to $\$ 3.50$ for large head sizes. California supplies over $90 \%$ of the total U.S. market, and the production value of artichoke in California is higher than that of any common vegetable crop grown in Texas (U.S. Department of Agriculture, 2004). Therefore, if commercial artichoke production is successfully established in Texas or regions with similar ecological conditions, this alternative crop could provide new market opportunities for regional agricultural economies.

There is a gap of knowledge on irrigation and $\mathrm{N}$ management for artichoke production in southern regions of the United States. Most research comes from Italy and Spain, the two leading producer countries in the world. Artichoke appears to have a high water requirement compared with other vegetable crops, in part as a result of the large foliage biomass and longer production cycle, up to 10 months when grown as annuals. A lysimeter experiment in Italy found that the maximum evapotranspiration (ET) of a seed-propagated artichoke cv. 044 was more than $900 \mathrm{~mm}$ in one season (Boari et al., 2000). In a 2-year study in Spain, when five different irrigation rates were applied with a sprinkler system on cv. Blanca de Tudela ecotype, yield and number of heads increased with increasing irrigation up to 630 $\mathrm{mm}$ (Macua et al., 2005). However, another study conducted with drip irrigation on $\mathrm{cv}$.
Imperial Star in Spain reported no yield differences between $100 \%$ and $125 \%$ of ETc, which was equivalent to $547 \mathrm{~mm}$ and $726 \mathrm{~mm}$ of total water applied (Pomares et al., 2004). Comparing irrigation methods for artichoke in Tunisia, water use efficiency was higher with drip $\left(24.2 \mathrm{~kg} \cdot \mathrm{ha}^{-1} \cdot \mathrm{mm}^{-1}\right)$ than furrow irrigation $\left(18.6 \mathrm{~kg} \cdot \mathrm{ha}^{-1} \cdot \mathrm{mm}^{-1}\right)$, which corresponded with a higher number of heads, seven and five heads per plant for the drip and furrow irrigation, respectively (Mansour et al., 2005).

Selecting an optimum $\mathrm{N}$ rate for artichoke crop management appears to be more complex than irrigation rate. A compositional $\mathrm{N}$ analysis of the foliage biomass (leaf + stem + heads) of artichoke showed that $400 \mathrm{~kg} \cdot \mathrm{ha}^{-1}$ of soil N was absorbed by the vegetatively propagated 'Blanca de Tudela' (Rincòn et al., 2007). Similarly, high $\mathrm{N}$ uptake, ranging from 388 to 625 $\mathrm{kg} \cdot \mathrm{ha}^{-1}$, was measured in seed-grown artichoke (Pomares et al., 2004). In California, artichoke growers usually apply 112 to 224 $\mathrm{kg} \cdot \mathrm{ha}^{-1} \mathrm{~N}$ (Schrader and Mayberry, 1997) and 150 to $280 \mathrm{~kg} \cdot \mathrm{ha}^{-1} \mathrm{~N}$ is applied in southeastern France (Ryder et al., 1983). Another study in Italy showed that when $\mathrm{N}$ was applied at $200 \mathrm{~kg} \cdot \mathrm{ha}^{-1}$, artichoke head weight and number were higher than nonfertilized controls (Paradiso et al., 2007). In contrast, a study in Spain reported minor yield differences when $\mathrm{N}$ was applied between 0 and $300 \mathrm{~kg} \cdot \mathrm{ha}^{-1}$ under furrow irrigation and between 0 and $270 \mathrm{~kg} \cdot \mathrm{ha}^{-1}$ under drip irrigation for 'Imperial Star' and cv. Num7144 (Pomares et al., 2004).

Artichoke contains high amounts of phenolic compounds, which have beneficial health effects resulting from their antioxidant capacity (Alamanni and Cossu, 2003; Curadi et al., 2005; Miccadei et al., 2008; Wang et al., 2003). A study conducted to investigate antioxidant sources in the American diet revealed that the antioxidant content of artichoke ranked fourth out of more than 1000 food products and was the highest over several selected vegetable crops (Halvorsen et al., 2006).

Two main phenolic compounds in artichoke are chlorogenic acid (5-O-caffeoylquinic acid) and cynarin (1,5-di- $O$-caffeoylquinic acid) (Schütz et al., 2004). Although many phenolic compounds have a strong antioxidative capacity when compared with vitamin $C$, vitamin $E$, and $\beta$-carotene (Vinson et al., 1995), the content of phenolics and their activity in artichoke may vary among plant parts and cultivars (Curadi et al., 2005; Romani et al., 2006; Wang et al., 2003) as well as head maturity, storage, and processing (Gil-Izquierdo et al., 2001; Halvorsen et al., 2006; Llorach et al., 2002; Wang et al., 2003). The impact of irrigation and $\mathrm{N}$ application rates on phenolic content in artichoke heads is also unknown.

The aim of this three-season study was to determine crop yield, quality, and nutritional components of fresh artichoke heads in response to differential irrigation regimes and $\mathrm{N}$ fertilizer rates. Selecting improved management practices for artichoke is a prerequisite to introduce this new crop into commercial production in southwest Texas and other semiarid regions of the United States. 


\section{Materials and Methods}

2005-2006 and 2006-2007 seasons (biennial system). A 2-year field experiment was conducted at the Texas A\&M AgriLife Research and Extension Center at Uvalde, TX (long. $29^{\circ} 13^{\prime} \mathrm{N}$, lat. $99^{\circ} 45^{\prime} \mathrm{W}$; elevation $283 \mathrm{~m}$ ). Winter (November to February) temperatures for 2005-2006, 2006-2007, and 2007-2008 seasons were generally similar with average daily temperatures in the range of 13.4 to $14.3^{\circ} \mathrm{C}$. The main difference among seasons was in 2005-2006, when the average temperature of January was significantly higher $\left(14.3^{\circ} \mathrm{C}\right)$ than the other seasons (Fig. 1). Pre-plant soil physical and chemical properties (0- to $13-\mathrm{cm}$ depth where we applied the $\mathrm{N}$ fertilizer) are summarized in Table 1. Two-month-old artichoke 'Imperial Star' (Condor Seed Production, Inc., Yuma, AZ) seedlings previously grown in a greenhouse in 128-cell polystyrene flats were transplanted to field beds $(\approx 2.03 \mathrm{~m}$ between rows, $\approx 0.76 \mathrm{~m}$ within row, equivalent to a plant population of 6465 plants/ha) on 16 Dec. 2005. After the 2005-2006 season harvest ended, plants were cut back to ground level on 19 July 2006 and new off-shoots were allowed to regrow for the 2006-2007 season production. Main plots were allocated to three irrigation regimes: $50 \%, 75 \%$, and $100 \%$ ETc rates. The values obtained for ETc were based on climatic parameters that are incorporated in the calculation of the reference evapotranspiration (ETo), which was updated daily from the lysimeter facility located at the experimental site and as described in Ko et al. (2009). The ETo values were adjusted by these phenological crop coefficients $(\mathrm{Kc})$, values as $\mathrm{Kc}$ ini $=$ $0.5, \mathrm{Kc}$ mid $=1.0, \mathrm{Kc}$ end $=0.95[$ Food and
Agriculture Organization of the United Nations (FAO), 1998] based on crop canopy characteristics with slight modifications. Irrigation was supplied using a subsurface drip system with drip tape placed in the middle of the bed, $15 \mathrm{~cm}$ below the soil surface, with emitters spaced every $30 \mathrm{~cm}$ and a flow rate of $340 \mathrm{~L} \cdot \mathrm{h}^{-1}$ per $100 \mathrm{~m}$ of bed at $69 \mathrm{kPa}$ (T-Tape 500 U.S. Model; T-systems International, San Diego, CA). Differential irrigation started after transplants were fully established on 31 Jan. 2006 (2005-2006 season) or after plants reached uniform growth on 17 Oct. 2006 (2006-2007 season). Total water inputs (irrigation + rainfall) for each irrigation regime during the experiment are described in Table 2. Subplots within main plots were allocated to four $\mathrm{N}$ fertilizer rates: $0,60,120$, and 180 $\mathrm{kg} \cdot \mathrm{ha}^{-1}$ applied as a granular ammonium nitrate $\left(\mathrm{NH}_{4} \mathrm{NO}_{3}\right)$ by sidedressing in two equal split doses, the first at stand establishment (20 Jan. 2006 for the 2005-2006 season and 9 Oct. 2006 for the 2006-2007 season) and the second at bud initiation (24 Mar. 2006 for the 2005-2006 season and 1 Feb. for the 20062007 season).

2007-2008 season (annual system). Based on the results of the first two seasons, a follow-up experiment was conducted in the same conditions as in the biennial system at a nearby location of the first two seasons, except for some modifications (i.e., fertilization, plasticulture, and within-plant spacing) aimed at optimizing growth and productivity. Twomonth-old artichoke seedlings 'Imperial Star' were transplanted to soil beds $(\approx 2.03 \mathrm{~m}$ between rows, $\approx 0.91 \mathrm{~m}$ within row, giving a plant population of 5390 plants/ha) covered by black plastic mulch $(0.038 \mathrm{~mm}$ thickness, $1.80 \mathrm{~m}$ width) on 24 Oct. 2007. In this last season, the average winter temperature $\left(14.3{ }^{\circ} \mathrm{C}\right)$ was similar to the other previous two seasons (Figs. 1 and 2). Although freezing temperatures (more than $5 \mathrm{~h}$ of continuous $0{ }^{\circ} \mathrm{C}$ or less) on $16,23,24$, and 25 Dec. 2007 and 3 and 8 Jan. 2008 caused leaf injury, drying mostly older but not younger leaves, all plants recovered soon after the freezes were over. Three differential irrigation rates were applied as previously described $(50 \%$, $75 \%$, and $100 \%$ ETc). Because black plastic mulch was used, evaporation from bare soil was deducted from the FAO's Kc (estimated Kc bare $=0.2$ ) and calculated in the water application under the mulch throughout the season. Therefore, the adjusted Kc values were $\mathrm{Kc}$ ini $=0.3, \mathrm{Kc}$ mid $=0.8$, and $\mathrm{Kc}$ end $=0.95$ with modifications based on canopy size. Irrigation water was supplied using a drip tape placed at $15 \mathrm{~cm}$ below the surface with emitters spaced every $30 \mathrm{~cm}$ and a flow rate of 170 $\mathrm{L} \cdot \mathrm{h}^{-1}$ per $100-\mathrm{m}$ bed at $69 \mathrm{kPa}$ (T-Tape 500 U.S. Model; T-systems International). Differential irrigation started after stand establishment on 28 Nov. 2007. Water inputs (irrigation + rainfall) during the experiment are described in Table 2. Four differential $\mathrm{N}$ rates: 10,60 , 120 , and $180 \mathrm{~kg} \cdot \mathrm{ha}^{-1}$ as liquid UAN were applied by fertigation (Fertijet; Netafim Irrigation Inc., Fresno, CA). A starter fertilizer of 10 $\mathrm{kg} \cdot \mathrm{ha}^{-1}$ of $\mathrm{N}$ (UAN, 32\%) was applied to all plots on 14 Nov. 2007 to enhance stand establishment. The rest of the $\mathrm{N}(0,50,110$, and 170 $\mathrm{kg} \cdot \mathrm{ha}^{-1}$ ) was applied in four equal split doses on 28 Nov. and 17 Dec. in 2007 and 8 Jan. and 5 Feb. in 2008.

Cultural practices. In addition to $\mathrm{N}$ applications, $56 \mathrm{~kg} \cdot \mathrm{ha}^{-1}$ of phosphorus and $60 \mathrm{~kg} \cdot \mathrm{ha}^{-1}$ of potassium were applied each season as a water-soluble granule nutrient mixture (Gainer

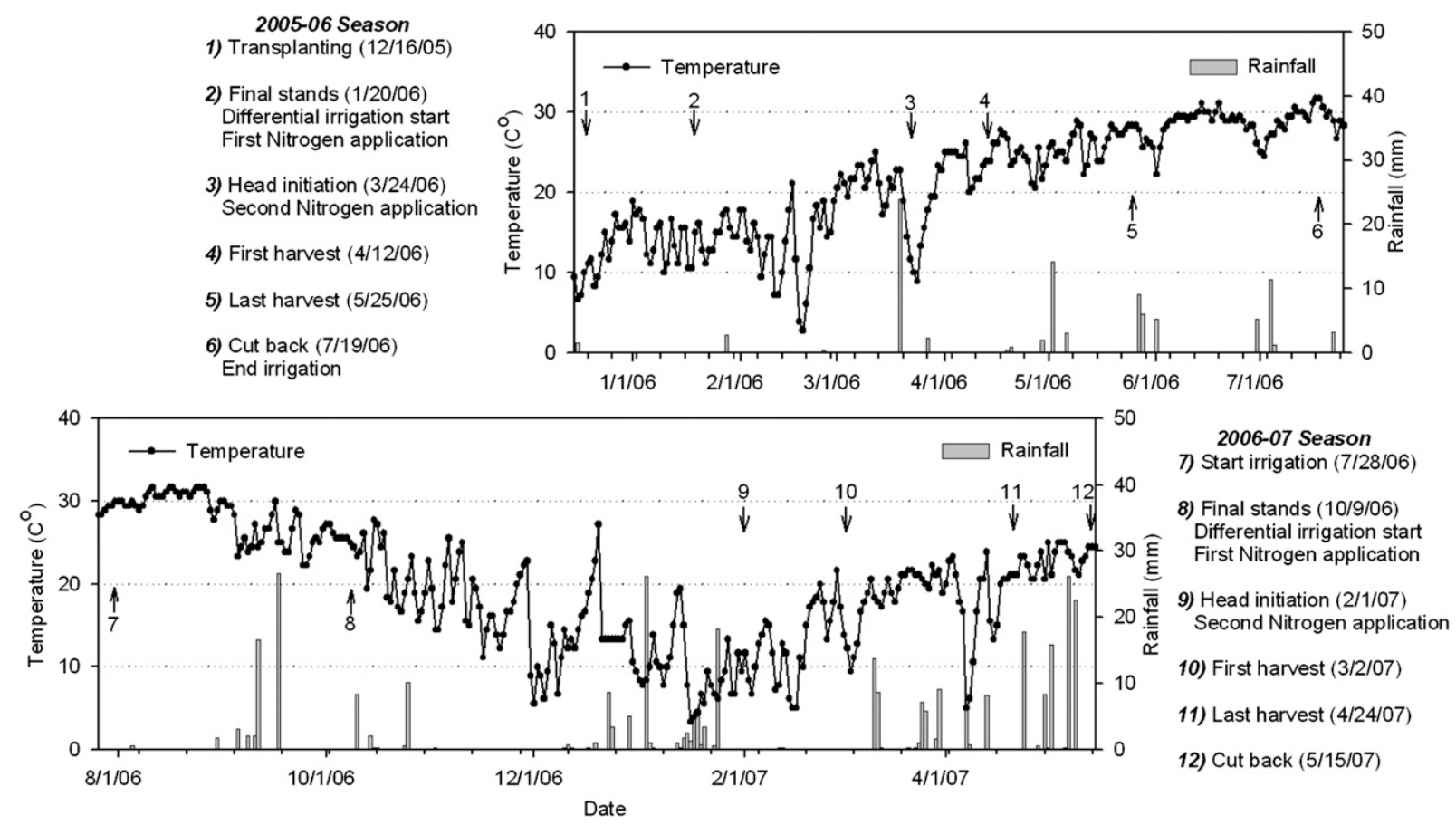

Fig. 1. Time course of average temperatures (solid lines), rainfall (bars) and specific agronomic practices (arrows) during the 2005-2006 and 2006-2007 seasons (biennial system); Uvalde, TX. 
Table 1. Physical and chemical properties of preplant soils for 2005-2007 seasons and 2007-2008 season, Uvalde, TX.

\begin{tabular}{lccc}
\hline Properties & & 2005 & \multicolumn{1}{c}{2007} \\
\hline Soil Texture & & Clay loam & Clay loam \\
Sand & $\%$ & 22 & 39 \\
Silt & $\%$ & 40 & 30 \\
Clay & $\%$ & 38 & 31 \\
pH & & 7.9 & 8.0 \\
EC & $\mathrm{dS} \cdot \mathrm{m}^{-1}$ & 0.4 & 0.4 \\
Organic carbon & $\%$ & 1.9 & 1.6 \\
Organic matter & $\%$ & 3.3 & 2.7 \\
Total nitrogen & $\mathrm{g} \cdot \mathrm{kg}^{-1}$ & 1.40 & 1.67 \\
$\mathrm{NH}_{4}-\mathrm{N}$ & $\mathrm{mg} \cdot \mathrm{kg}^{-1}$ & 3.7 & 68.2 \\
$\mathrm{NO}_{3}-\mathrm{N}$ & $\mathrm{mg} \cdot \mathrm{kg}^{-1}$ & 77.4 & 7.0 \\
$\mathrm{P}$ & $\mathrm{mg} \cdot \mathrm{kg}^{-1}$ & 64.6 & 54.0 \\
$\mathrm{~K}$ & $\mathrm{mg} \cdot \mathrm{kg}^{-1}$ & 717.0 & 861.0 \\
$\mathrm{Ca}$ & $\mathrm{mg} \cdot \mathrm{kg}^{-1}$ & $14,320.7$ & $17,643.0$ \\
$\mathrm{Mg}$ & $\mathrm{mg} \cdot \mathrm{kg}^{-1}$ & 243.7 & 382.0 \\
$\mathrm{~S}$ & $\mathrm{mg} \cdot \mathrm{kg}^{-1}$ & 40.4 & 33.0 \\
$\mathrm{Na}$ & $\mathrm{mg} \cdot \mathrm{kg}^{-1}$ & 143.9 & 163.0 \\
$\mathrm{Fe}$ & $\mathrm{mg} \cdot \mathrm{kg}^{-1}$ & 2.7 & 46.2 \\
$\mathrm{Zn}$ & $\mathrm{mg} \cdot \mathrm{kg}^{-1}$ & 1.1 & 13.8 \\
$\mathrm{Mn}$ & $\mathrm{mg} \cdot \mathrm{kg}^{-1}$ & 9.7 & 8.4 \\
$\mathrm{Cu}$ & $\mathrm{mg} \cdot \mathrm{kg}^{-1}$ & 0.5 & 0.4 \\
\hline $\mathrm{S}$ & &
\end{tabular}

Soil samples (0- to $13-\mathrm{cm}$ depth) were collected before planting on 12 Dec. 2005 for the 2005-2006 and 2006-2007 seasons and on 23 Oct. 2007 for the 2007-2008 season.
0-50-30 with $0.02 \%$ boron, $0.05 \%$ copper, $0.1 \%$ iron, $0.05 \%$ manganese, $0.0005 \%$ molybdenum, and $0.05 \%$ zinc; RSA MicroTech, LLC, Marysville, WA). These nutrients were applied in four split doses with 40\%:20\%:20\%: $20 \%$ on 19 Dec. 2005, 31 Jan., 8 Feb., and 6 Apr. 2006 for the 2005-2006 season and on 9 Aug., 9 Oct., 21 Dec. 2006, and 21 Feb. 2007 for the 2006-2007 season and on 31 Oct., 28 Nov., 18 Dec. 2007, and 9 Jan. 2008 for the 2007-2008 season, respectively. Supplemental calcium and zinc (Ca-Zn, $5 \% \mathrm{Ca}$, and $2.5 \% \mathrm{Zn}$; Tracite; Helena Chemical Co., Fresno, CA) were applied biweekly as foliar sprays with a $\mathrm{CO}_{2}$ backpack sprayer during the harvesting period in the 2005-2006 and 2006-2007 seasons and during the whole growing period in the 2007-2008 season. Weeds were controlled by a pre-plant application of $1.1 \mathrm{~kg} \cdot \mathrm{ha}^{-1}$ of diuron (Diuron 80DF, $80 \%$ a.i.; Winfield Solutions LLC, St. Paul, MN) and $5.8 \mathrm{~L} \cdot \mathrm{ha}^{-1}$ of oxyflurofen (Goal 2XL, 23\% a.i.; Dow AgroSciences LLC, Indianapolis, IN) and by hand weeding throughout the cropping seasons, if necessary. Control against cucumber beetle (Diabrotica undecimpunctata) during the vegetative stage was performed with a single foliar spray of $2.3 \mathrm{~L} \cdot \mathrm{ha}^{-1}$ of endosulfan (Endosulfan 3EC, 34\% a.i.; Drexel Chemical Co., Memphis, TN) (2006-2007 season) or by periodic applications of $70 \mathrm{~mL} \cdot \mathrm{ha}^{-1}$ of esfenvalerate (Asana XL, 8.4\% a.i.; DuPont, Wilmington, DE) (2007-2008 season). To control aphids (Myzus persicae), spider mites (Tetranychus sp.), and corn earworm (Helicoverpa zea) during the growing season, $580 \mathrm{~mL} \cdot \mathrm{ha}^{-1}$ of imidacloprid (Provado 1.6, 17.4\% a.i.; Bayer CropScience LP, Research Triangle Park, NC) and/or $420 \mathrm{~g} \cdot \mathrm{ha}^{-1}$ of bifenthrin (Capture 2EC, $25.1 \%$ a.i.; FMC Corp., Philadelphia, PA) was used when needed in all seasons. During late spring to late summer in 2006, some artichoke younger offshoots were suddenly wilted, leading to death caused by cotton root rot (Phymatotrichum omnivorum). To our knowledge, this is the first evidence of cotton root rot disease on artichokes as identified by M.C. Black, plant pathologist at Texas A\&M AgriLife Extension at Uvalde.

Marketable yield and yield components. Harvests occurred periodically between 12 Apr. and 25 May 2006 for the 2005-2006 season, between 2 Mar. and 24 Apr. 2007 for the 2006-2007 season, and between 20 Mar.

Table 2. Frequency (no.) and amount (mm) of irrigation applied or rainfall received during the 2005-2006, 2006-2007, and 2007-2008 seasons; Uvalde, TX.

\begin{tabular}{|c|c|c|c|c|c|c|c|c|c|c|c|}
\hline \multicolumn{12}{|c|}{ Frequency and amount of irrigation and rainfall } \\
\hline & June-Aug. & Sept. & Oct. & Nov. & Dec. & Jan. & Feb. & Mar. & Apr. & May & Total applied \\
\hline \multicolumn{12}{|c|}{$2005-2006$ season } \\
\hline $75 \%$ ETc & - & - & - & - & $6-136^{2}$ & $6-57$ & $5-41$ & $6-56$ & 10-119 & $13-179$ & $46-587$ \\
\hline $100 \%$ ETc & - & - & - & - & $6-136^{2}$ & $6-60$ & $5-53$ & $6-72$ & $10-161$ & $13-234$ & $46-716$ \\
\hline Rainfall & - & - & - & - & $1-1.5$ & $1-2.8$ & $2-0.8$ & $3-26$ & $3-3.6$ & $4-33$ & $14-68$ \\
\hline \multicolumn{12}{|c|}{ 2006-2007 season } \\
\hline $75 \%$ ETc & $29-256^{y}$ & $10-75$ & $6-59$ & $6-61$ & $3-32$ & $0-0$ & $6-68$ & $5-62$ & $7-81$ & - & $72-694$ \\
\hline $100 \%$ ETc & $29-256^{y}$ & $10-75$ & $6-68$ & $6-81$ & $3-42$ & $0-0$ & $6-90$ & $5-87$ & $7-109$ & - & $72-809$ \\
\hline Rainfall & $10-37$ & $5-50$ & $6-22$ & $1-0.3$ & $8-20$ & $14-68$ & $2-0.5$ & $11-48$ & $4-44$ & - & $61-288$ \\
\hline \multicolumn{12}{|c|}{ 2007-2008 season } \\
\hline $50 \%$ ETc & - & - & $6-22^{x}$ & $6-18$ & $3-9$ & $4-12$ & $7-25$ & $7-39$ & $7-54$ & - & $40-179$ \\
\hline $75 \%$ ETc & - & - & $6-22^{x}$ & $6-18$ & $4-14$ & $5-18$ & $9-38$ & $12-58$ & $14-80$ & - & $56-248$ \\
\hline
\end{tabular}

${ }^{2}$ Values include $112 \mathrm{~mm}$ of pre-planting irrigation (four times).

${ }^{\mathrm{y}}$ Values include $69 \mathrm{~mm}$ of pre-awaking irrigation (seven times)

${ }^{x}$ Values include $12 \mathrm{~mm}$ of pre-planting irrigation (two times).

$\mathrm{ETc}=$ crop evapotranspiration.

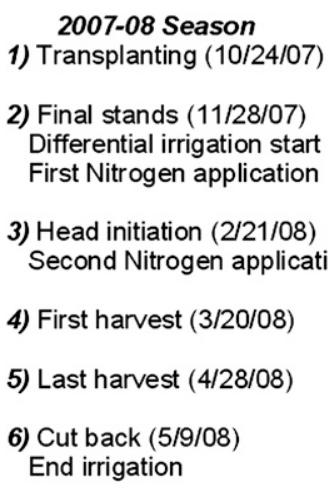

2007-08 Season
1) Transplanting $(10 / 24 / 07)$

2) Final stands $(11 / 28 / 07)$

Differential irrigation start

Head initiation $(2 / 21 / 08)$

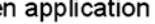

5) Last harvest (4/28/08)

Cut back (5/9/08)

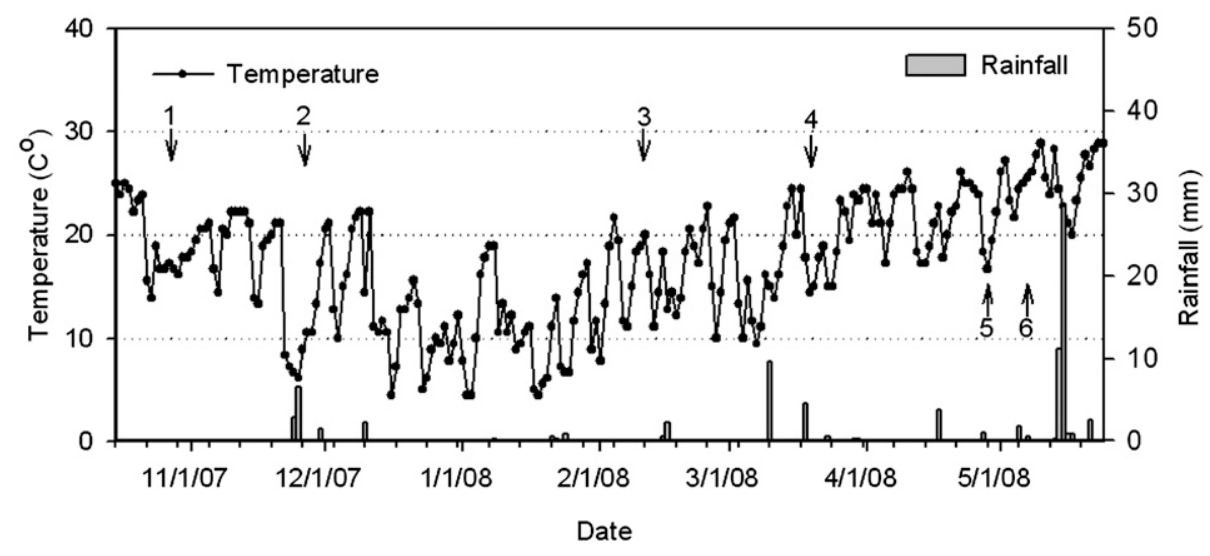

Fig. 2. Time course of temperature (solid lines), rainfall (bars) and specific agronomic practices (arrows) during the 2007-2008 season (annual system); Uvalde, TX. 
and 28 Apr. 2008 for the 2007-2008 season. Marketable yield $\left(\mathrm{kg} \cdot \mathrm{ha}^{-1}\right)$, head weight $(\mathrm{g})$, and head number per plant (no./plant) were recorded. Water use efficiency (WUE) was calculated as kilograms of heads per water input $\left(\mathrm{kg} \cdot \mathrm{ha}^{-1} \cdot \mathrm{mm}^{-1}\right)$.

Head size distribution. Artichoke head size (considered a quality component) was determined during harvesting. Harvest periods were separated as early and late. Early harvests were done on 13, 20, and 26 Apr. and 3 May 2006 for the 2005-2006 season; 2, 12, 19, 23, and 28 Mar. 2007 for the 2006-2007 season; and 20, 24, and 28 Mar. and 1, 4, and 7 Apr. 2008 for the 2007-2008 season. Late harvests were done on 8, 12, 18, and 25 May for the 20052006 season; 3, 10, 16, and 24 Apr. 2007 for the 2006-2007 season; and 11, 14, 18, 21, 25, and 28 Apr. 2008 for the 2007-2008 season. Head size was classified into marketable heads by diameter; small (less than $7 \mathrm{~cm}$ ), medium ( 7 to $9 \mathrm{~cm}$ ), large ( 9 to $11 \mathrm{~cm}$ ), or jumbo (greater than $11 \mathrm{~cm}$ ). Unmarketable heads were those with tip burn and open bracts.

Soil nitrogen. Soil residual N was measured to determine soil $\mathrm{N}$ availability. Soil sampling (0- to $13-\mathrm{cm}$ depth) was performed on 27 July 2006 for the 2005-2006 season, on 25 June 2007 for the 2006-2007 season, and 12 May 2008 for the 2007-2008 season. Nitrate-N $\left(\mathrm{NO}_{3}-\mathrm{N}, \mathrm{mg} \cdot \mathrm{kg}^{-1}\right)$ was extracted from soils using a $1 \mathrm{~N} \mathrm{KCl}$ solution. Nitrate was determined by reduction of nitrate $\left(\mathrm{NO}_{3}\right.$ $\mathrm{N})$ to nitrite using a cadmium column followed by spectrophotometric measurement. Ammonium- $\mathrm{N}\left(\mathrm{NH}_{4}-\mathrm{N}\right)$ was extracted from soils using a $1 \mathrm{~N} \mathrm{KCl}$ solution. Ammonium-N was determined spectrophotometrically at $420 \mathrm{~nm}$ wavelength. Soil $\mathrm{N}$ analysis was conducted at the Texas A\&M Soil, Water and Forage Testing Laboratory in College Station, TX.

Sample preparation for phenolic compounds. Total phenolics, chlorogenic acid, and cynarin content of artichoke heads were determined during harvest at three times (separated as early, mid, and late). Early harvests were done on 20 Apr. 2006 for the 2005-2006 season and 23 Mar. 2007 for the 2006-2007 season, but not in the 2007-2008 season. Midharvests were done on 3 May 2006 for the 2005-2006 season, 3 Apr. 2007 for the 20062007 season, and 1 Apr. 2008 for the 20072008 season. Late harvests were done on 25 May 2006 for the 2005-2006 season, 24 Apr. 2007 for the 2006-2007 season, and 21 Apr. 2008 for the 2007-2008 season. Before analysis, outer bracts were removed keeping the stems (5 cm length), chopped, dried in an oven at $70{ }^{\circ} \mathrm{C}$ until constant weight, and ground to make powder samples, which were kept in sealed plastic bags until analysis. All analyses (methods described subsequently) were conducted at the Vegetable and Fruit Improvement Center (VFIC), College Station, TX.

Colorimetric analysis of total phenolics. Total phenolics content was measured using the Folin-Ciocalteu assay (Singleton and Rossi, 1965). A 2-g dried sample of artichoke head was mixed with $30 \mathrm{~mL} 80 \%$ ethanol and shaken for $24 \mathrm{~h}$ and the ethanol extract was used for total phenolic measurements. Extracts of $50 \mu \mathrm{L}$ were mixed well with $9 \mathrm{~mL}$ of nano pure water in a $15-\mathrm{mL}$ test tube. A $0.5-\mathrm{mL}$ Folin-Chiocalteu reagent was added, mixed well, and left to settle for $5 \mathrm{~min}$. A $1.5-\mathrm{mL}$ aliquot of $\mathrm{Na}_{2} \mathrm{CO}_{3}$ solution $(20 \mathrm{~g} / 100 \mathrm{~mL})$ was added, mixed well again, and kept for $2 \mathrm{~h}$ at room temperature. Total phenolics content was determined by a spectrophotometer (Spectronic 601; Milton Roy USA, Ivyland, PA) with absorbance at $760 \mathrm{~nm}$. The content was standardized against chlorogenic acid with a linearity ranging from $15.6 \mathrm{mg} \cdot \mathrm{L}^{-1}$ to 2030 $\mathrm{mg} \cdot \mathrm{L}^{-1}$. The final value was converted to milligrams per gram dry weight $\left(\mathrm{mg} \cdot \mathrm{g}^{-1} \mathrm{DW}\right)$.

High-performance liquid chromatography analysis of chlorogenic acid and cynarin. The ethanol extract used in the total phenolic analysis was used for chlorogenic acid and cynarin analysis using a high-performance liquid chromatography (HPLC) system. Standard commercial compounds for cynarin (identified as 1,3-di-O-caffeoylquinic acid; Roth, Karlsruhe, Germany) and chlorogenic acid (Sigma, St. Louis, MO) were used. A major cynarin isomer, 1,5-di-O-caffeoylquinic acid, was purified from the concentrated ethanol extract by using a preparative column (Econosil C-18, $10 \mu \mathrm{m}$; Alltech, Deerfield, IL) with $4 \mathrm{~mL} \cdot \mathrm{min}^{-1}$ methanol gradient from $20 \%$ to $90 \%$ in $30 \mathrm{~min}$. A $150-\mu \mathrm{L}$ concentrated extract was injected and the matching fraction of the peak was collected. The concentration of the fraction was calculated by measuring absorbance at $326 \mathrm{~nm}$ (E $1 \%, 1 \mathrm{~cm}=616$; Merck Index Eleventh Edition, Rahway, NJ). The same fraction was injected into the HPLC and the peak area was obtained and used as an external standard of 5$O$-caffeolylquinic acid, which was confirmed as chlorogenic acid by a matching spectrum max at $326 \mathrm{~nm}$ using a diode array detector. The commercial cynarin and chlorogenic acid were also run by HPLC and calibrated as external standards. The purity of the purified standard was similar to or better than the commercial ones. The HPLC column used was a Waters Spherisorb ODS-2, $5 \mu \mathrm{m}$ (4.6 $\times$ $250 \mathrm{~mm}$ ), Milford, MA. The solvent was programmed with $10 \%$ to $50 \%$ acetonitrile containing $0.5 \%$ phosphoric acid in $20 \mathrm{~min}$. The flow was $1 \mathrm{~mL} \cdot \mathrm{min}^{-1}$, and after a $5-\mu \mathrm{L}$ sample was injected, the detection was made at $326 \mathrm{~nm}$. Cynarin content was determined by the isomer 1,5-di-O-caffeoylquinic acid, which is a major cynarin isomer in artichoke heads (Schütz et al., 2004).

Plant physiological responses. Midday net photosynthetic rate $\left(\mathrm{A}_{\mathrm{CO} 2}, \mu \mathrm{mol} \cdot \mathrm{m}^{-2} \cdot \mathrm{s}^{-1}\right)$, transpiration $\left(\mathrm{E}, \mathrm{mmol} \mathrm{H}_{2} \mathrm{O} \mathrm{m}^{-2} \cdot \mathrm{s}^{-1}\right)$, and stomatal conductance $\left(g_{\mathrm{s}}, \mathrm{mol} \cdot \mathrm{m}^{-2} \cdot \mathrm{s}^{-1}\right)$ were determined for plants growing in the 2007-2008 season. Measurements were conducted with a portable photosynthesis system (LI-6400; LI-COR Inc, Lincoln, NE) on 8 Feb., 21 Mar., 10 Apr., and 2 May 2008 and the light intensity, atmospheric $\mathrm{CO}_{2}$ concentration, and stomatal ratio were adjusted to $1500 \mu \mathrm{mol} \cdot \mathrm{m}^{-2} \cdot \mathrm{s}^{-1}$ photosynthetically active radiation, $400 \mathrm{mg} \cdot \mathrm{L}^{-1}$, and 0.8 as cited in Brutti et al. (2002), respectively.

Statistical analysis. The experiments over the first two seasons 2005-2006 and 20062007 were conducted using a split plot design with four replications; each plot consisted of 13 plants with a total area of $20 \mathrm{~m}^{2}$. Irrigation regime was assigned to the main plot and $\mathrm{N}$ rates to the subplots.

For the 2007-2008 season, the experiment was conducted using a randomized complete block design with four replications of seven plants each and a total plot area of $12.8 \mathrm{~m}^{2}$. Plant physiological measurements were taken over time with replicated measurements (twice, total eight plants). All data were statistically analyzed by analysis of variance using SPSS (Version 14.0 for Windows; SPSS Inc., Chicago, IL). Differences among irrigation and N rate were determined using least significant difference at $P \leq 0.05$. Trend analysis for yield in response to $\mathrm{N}$ rates was obtained using polynomial contrasts.

\section{Results}

Precipitation and irrigation. Total rainfall during the crop cycle was $68 \mathrm{~mm}$ in 20052006, $288 \mathrm{~mm}$ in 2006-2007, and $38 \mathrm{~mm}$ in 2007-2008, respectively. Therefore, the first and third seasons were considered dry, whereas the second wet. Large amounts of rainfall in 2006-2007 were in part the result of more precipitation in Jan., Mar., and Apr. 2006 as compared with the other two seasons (Table 2).

Total irrigation applied during the crop cycles for the $100 \%$ ETc was $716 \mathrm{~mm}$ in 2005-2006, $809 \mathrm{~mm}$ in 2006-2007, and 317 $\mathrm{mm}$ in 2007-2008 (black plastic mulch applied). Frequent irrigations occurred during harvest in 2005-2006 and 2007-2008 but not in the 2006-2007 season as a result of the large number of precipitation events during the harvesting period. Overall, under plastic mulch, the amount of irrigation applied in 2007-2008 was $56 \%$ and $61 \%$ less than 2005-2006 and 2006-2007 seasons, respectively (Table 2).

Yield and yield components. There were not significant irrigation and nitrogen interactions for yield, yield components, or WUE. In the 2005-2007 seasons, marketable yields significantly increased at $100 \%$ ETc $(13,153$ and $15,696 \mathrm{~kg} \cdot \mathrm{ha}^{-1}$ ) as compared with deficit irrigation at $50 \%$ ETc (Table 3 ). Nitrogen did not significantly affect yield in both seasons, although there was a slight linear $(P=0.108)$ yield increase in the 2006-2007 season. The highest numerical (but not statistically at $P \leq$ 0.05 ) yields were achieved in the second season with $100 \%$ ETc and $120 \mathrm{~kg} \cdot \mathrm{ha}^{-1} \mathrm{~N}$ $\left(17,626 \mathrm{~kg} \cdot \mathrm{ha}^{-1}\right)$ (data not shown). Higher irrigation rates significantly increased head number in both seasons and head weight in the 2005-2006 season (Table 3).

WUE was unaffected by either irrigation or $\mathrm{N}$ rates. The higher values of WUE in the 2005-2006 compared with the 2006-2007 season were because less water inputs were applied as a result of a shorter crop cycle, 6 months in the 2005-2006 compared with 9 months in the 2006-2007 season (Fig. 1; Table 3).

In the 2007-2008 season, marketable yield significantly increased at $100 \%$ ETc $(16,962$ $\mathrm{kg} \cdot \mathrm{ha}^{-1}$ ), whereas a $30 \%$ yield reduction was measured at $50 \%$ ETc (Table 3). Similarly, 
both head number and weight significantly increased with higher irrigation rates as also shown in the 2005-2006 season. However, yields were not significantly affected by $\mathrm{N}$ rates (Table 3 ). WUE was only affected by irrigation rates, being significantly higher at both deficit irrigation rates as compared with 100\% ETc (Table 3).

Head size distribution. In the 2005-2006 season, a higher proportion of medium heads was obtained with $75 \%$ ETc compared with $50 \%$ ETc at the late harvest. The proportion of heads with open bracts (unmarketable) was significantly lower at $75 \%$ ETc compared with $100 \%$ ETc at late harvest (Fig. 3), whereas tip burn significantly increased with $50 \%$ ETc and higher $\mathrm{N}$ rates (120 and 180 $\mathrm{kg} \cdot \mathrm{ha}^{-1} \mathrm{~N}$ ) at late harvest (data not shown).

In the 2006-2007 season, the variability of head size was smaller than the 2005-2006 season and the majority of heads were of medium size, ranging from $67 \%$ to $74 \%$ of total heads. Overall, irrigation and $\mathrm{N}$ rates did not affect the proportion of marketable heads, but a higher proportion of unmarketable heads with tip burn resulted from $50 \%$ and $75 \%$ ETc at the late harvest (Fig. 3).
In the 2007-2008 season, the proportion of marketable heads was clearly affected by irrigation rates. In the early harvest, jumbo heads accounted for $27 \%$ and large heads for $73 \%$ at $100 \%$ ETc as compared with $15 \%$ jumbo and $85 \%$ large at $50 \%$ ETc (Fig. 3). A similar trend of head size distribution was measured in the late season, which had a higher proportion of large heads (38\%) and correspondingly a smaller proportion of medium heads $(48 \%)$ at $100 \%$ ETc compared with deficit irrigation at $50 \%$ ETc (57\%). Overall, N did not significantly affect marketable or unmarketable head sizes.

Soil nitrogen. Soil N content at $0-$ to $13-\mathrm{cm}$ depth was evaluated at the end of each crop cycle for 2005-2006, 2006-2007, and 20072008 seasons. Pre-plant soil $\mathrm{NH}_{4}-\mathrm{N}$ and $\mathrm{NO}_{3}-$ $\mathrm{N}$ were 3.7 and $77.4 \mathrm{mg} \cdot \mathrm{kg}^{-1}$ and 68.2 and 7.0 $\mathrm{mg} \cdot \mathrm{kg}^{-1}$ in 2005-2006 and 2007-2008 seasons, respectively (Table 1). Irrigation did not affect soil $\mathrm{NH}_{4}-\mathrm{N}$ and $\mathrm{NO}_{3}-\mathrm{N}$ when measured after the 2005-2006 season harvest. Both $\mathrm{NH}_{4}$ $\mathrm{N}$ and $\mathrm{NO}_{3}-\mathrm{N}$ were significantly affected by $\mathrm{N}$ rates with the highest at $180 \mathrm{~kg} \cdot \mathrm{ha}^{-1} \mathrm{~N}$ (Table 4). The partitioning of the significant irrigation $\times \mathrm{N}$ interaction for $\mathrm{NO}_{3}-\mathrm{N}$ in the 2005-2006 season showed that the highest concentration of $\mathrm{NO}_{3}-\mathrm{N}$ present in the soil resulted with a combination of $180 \mathrm{~kg} \cdot \mathrm{ha}^{-1} \mathrm{~N}$ and higher irrigation rates both at $75 \%$ and $100 \%$ ETc (Fig. 4). In the 2006-2007 season, there were not significant differences among both irrigation and $\mathrm{N}$ treatments (Table 4). In the 2007-2008 season, the partitioning of the significant irrigation and $\mathrm{N}$ interaction for $\mathrm{NO}_{3}-\mathrm{N}$ (Table 4), indicated that the highest concentration of soil $\mathrm{NO}_{3}-\mathrm{N}$ also resulted from the combination of $180 \mathrm{~kg} \cdot \mathrm{ha}^{-1} \mathrm{~N}$ and $100 \%$ ETc (Fig. 4), although a differential fertilization method was adopted in the 2007-2008 (fertigation with UAN) compared with 2005-2006 season (sidedressing with $\mathrm{NH}_{4} \mathrm{NO}_{3}$ ).

Phenolic contents. In the 2005-2006 season, for all harvest periods, total phenolic content in heads significantly increased (up to $15 \%$ ) with deficit irrigation at $50 \%$ ETc as compared with $75 \%$ and $100 \% \mathrm{ETc}$, whereas it was unaffected by $\mathrm{N}$ rates (not shown). However, the partitioning of the significant irrigation $\times$ harvest time interaction for phenolic content in the first season (Fig. 5) indicated that heads from the mid- and late harvests had higher phenolics content at $50 \%$ ETc but not at $75 \%$ and $100 \%$ ETc. In that season, total

Table 3. Marketable yield, head number, head weight, and water, and use efficiency (WUE) of artichoke 'Imperial Star' in response to irrigation and nitrogen rate, 2005-2008 seasons.

\begin{tabular}{|c|c|c|c|c|c|c|c|c|c|c|c|c|}
\hline \multirow{2}{*}{ Treatment } & \multicolumn{4}{|c|}{ 2005-2006 season } & \multicolumn{4}{|c|}{ 2006-2007 season } & \multicolumn{4}{|c|}{$2007-2008$ season } \\
\hline & $\frac{\text { Yield }}{\left(\mathrm{kg} \cdot \mathrm{ha}^{-1}\right)}$ & \multicolumn{2}{|c|}{ Head } & $\frac{\text { WUE }}{\left(\mathrm{kg} \cdot \mathrm{ha}^{-1} \cdot \mathrm{mm}^{-1}\right)}$ & $\frac{\text { Yield }}{\left(\mathrm{kg}^{\prime} \mathrm{ha}^{-1}\right)}$ & \multicolumn{2}{|c|}{ Head } & $\frac{\mathrm{WUE}}{\left(\mathrm{kg} \cdot \mathrm{ha}^{-1} \cdot \mathrm{mm}^{-1}\right)}$ & $\frac{\text { Yield }}{\left(\mathrm{kg}^{\prime} \mathrm{ha}^{-1}\right)}$ & \multicolumn{2}{|c|}{ Head } & $\frac{\text { WUE }}{\left(\mathrm{kg} \cdot \mathrm{ha}^{-1} \cdot \mathrm{mm}^{-1}\right)}$ \\
\hline \multicolumn{13}{|l|}{$\overline{\text { Irrigation }(\mathrm{I})}$} \\
\hline $75 \%$ ETc & $11,571 \mathrm{~b}$ & $11.1 \mathrm{~b}$ & $187.2 \mathrm{a}$ & 19.3 & $14,311 \mathrm{~b}$ & $11.6 \mathrm{~b}$ & 240.2 & 15.5 & $15,704 \mathrm{~b}$ & $11.7 \mathrm{a}$ & $301.3 \mathrm{~b}$ & $54.9 \mathrm{a}$ \\
\hline $100 \%$ ETc & $13,153 \mathrm{a}$ & $12.3 \mathrm{a}$ & $188.2 \mathrm{a}$ & 18.2 & $15,696 \mathrm{a}$ & $12.9 \mathrm{a}$ & 246.4 & 15.1 & $16,962 \mathrm{a}$ & $12.3 \mathrm{a}$ & $312.4 \mathrm{a}$ & $47.8 \mathrm{~b}$ \\
\hline \multicolumn{13}{|l|}{ Nitrogen $(\mathrm{N})$} \\
\hline $0-10 \mathrm{~kg} \cdot \mathrm{ha}^{-1}$ & 11,305 & 10.8 & 181.1 & 19.0 & 12,669 & 10.6 & 227.7 & 13.7 & 14,258 & 10.7 & 293.1 & 50.5 \\
\hline $180 \mathrm{~kg} \cdot \mathrm{ha}^{-1}$ & 10,730 & 10.3 & 180.6 & 18.0 & 14,728 & 12.0 & 246.0 & 16.0 & 15,464 & 11.3 & 303.5 & 54.7 \\
\hline
\end{tabular}

${ }^{\mathrm{z}}$ Mean within columns followed by different letter are significantly different (least significant difference, $P \leq 0.05$ )

Non-significant irrigation and nitrogen interactions for yield components.

Non-significant linear $(P=0.218,0.108$, and 0.131 for 2005-2006, 2006-2007, and 2007-2008 seasons, respectively) and quadratic trends $(P=0.740,0.336$, and 0.722 for 2005-2006, 2006-2007, and 2007-2008 seasons, respectively) for yield in response to $\mathrm{N}$ rates.

ETc, crop evapotranspiration.
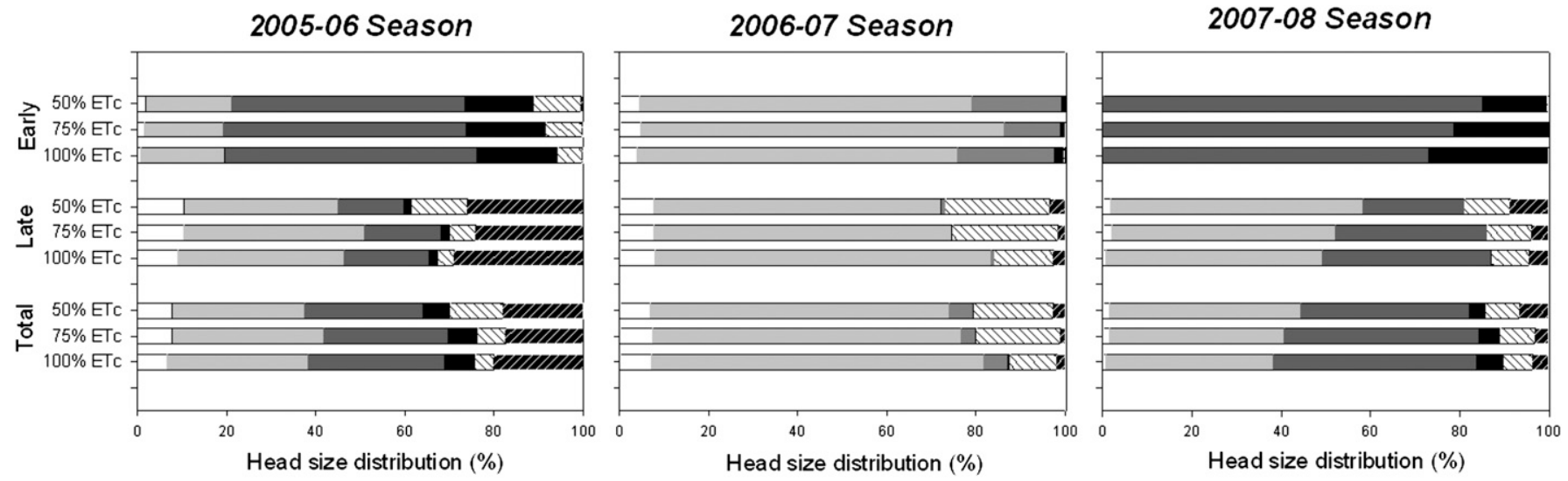

$\square<7 \mathrm{~cm} \square 7-9 \mathrm{~cm} \square 9-11 \mathrm{~cm}=>11 \mathrm{~cm}$ Tip burn wors Open bracts

Fig. 3. Marketable head size distribution by diameter [small (less than $7 \mathrm{~cm}$ ), medium (7 to $9 \mathrm{~cm}$ ), large (9 to $11 \mathrm{~cm}$ ), or jumbo (greater than $11 \mathrm{~cm})$ ] and unmarketable heads (tip burn and open bracts) of artichoke 'Imperial Star' in response to harvest time (early, late, and total) and irrigation rates in the 20052006 season (left), the 2006-2007 season (middle), and the 2007-2008 season (right). 
phenolic content also decreased with the highest rate of $180 \mathrm{~kg} \cdot \mathrm{ha}^{-1} \mathrm{~N}$ at the late harvest (Fig. 5)

In the 2006-2007 season, neither irrigation nor $\mathrm{N}$ rates affected phenolic content in any of the three harvests (Fig. 5). Comparing harvest time, total phenolics significantly increased by $\approx 30 \%$ in the late compared with early harvest (Fig. 5). Similarly, irrigation and $\mathrm{N}$ rates did not affect phenolics content in the 2007-2008 season (not shown).

Chlorogenic acid and cynarin are the main phenolic compounds present in artichoke heads. The partitioning of the significant irrigation and harvest time interaction for the 2005-2006 season is depicted in Figure 6. Chlorogenic acid significantly increased with deficit irrigation for late and mid harvests and was maximized ( $\left.13 \mathrm{mg} \cdot \mathrm{g}^{-1} \mathrm{DW}\right)$ at $50 \%$ ETc for the late harvest The trend for cynarin content was relatively similar to that of chrologenic acid content (Fig. 6). Overall $\mathrm{N}$ rates had minimal effects on chlorogenic acid and cynarin content at each harvest time.

Plant physiological responses. Net photosynthetic rate was significantly reduced by deficit irrigation at $50 \%$ ETc as compared with $75 \%$ and $100 \%$ ETc. This effect was more evident as the season progressed from 21 Mar. to 2 May 2008 [149 to $191 \mathrm{~d}$ after transplanting (DAT)]. Nitrogen rates did not affect $\mathrm{A}_{\mathrm{CO} 2}$ except 191 DAT. At that time, plants receiving $180 \mathrm{~kg} \cdot \mathrm{ha}^{-1} \mathrm{~N}$ showed higher $\mathrm{A}_{\mathrm{CO} 2}$ than at lower $\mathrm{N}$ rates (Fig. 7).

Deficit irrigation $(50 \%$ ETc) significantly reduced transpiration compared with higher irrigation rates, and the difference was more pronounced later in development. However, transpiration was similar among $\mathrm{N}$ rates, except 191 DAT, the time at which transpiration was also highest with $180 \mathrm{~kg} \cdot \mathrm{ha}^{-1} \mathrm{~N}$ (Fig. 7). Similarly, $g_{\mathrm{S}}$ was clearly lower with deficit irrigation $(50 \%$ ETc) compared with $75 \%$ and $100 \%$ ETc throughout the growing season.

Table 4. Soil nitrogen (N) content after harvest for artichoke 'Imperial Star' in response to irrigation and $\mathrm{N}$ rates, 2005-2008 seasons.

\begin{tabular}{|c|c|c|c|c|c|c|}
\hline & \multicolumn{2}{|c|}{ 2005-2006 season } & \multicolumn{2}{|c|}{ 2006-2007 season } & \multicolumn{2}{|c|}{ 2007-2008 season } \\
\hline & $\begin{array}{c}\mathrm{NH}_{4}-\mathrm{N} \\
\left(\mathrm{mg} \cdot \mathrm{kg}^{-1}\right)\end{array}$ & $\begin{array}{c}\mathrm{NO}_{3-}-\mathrm{N} \\
\left(\mathrm{mg} \cdot \mathrm{kg}^{-1}\right)\end{array}$ & $\begin{array}{c}\mathrm{NH}_{4}-\mathrm{N} \\
\left(\mathrm{mg} \cdot \mathrm{kg}^{-1}\right)\end{array}$ & $\begin{array}{c}\mathrm{NO}_{3}-\mathrm{N} \\
\left(\mathrm{mg} \cdot \mathrm{kg}^{-1}\right)\end{array}$ & $\begin{array}{c}\mathrm{NH}_{4}-\mathrm{N} \\
\left(\mathrm{mg} \cdot \mathrm{kg}^{-1}\right)\end{array}$ & $\begin{array}{c}\mathrm{NO}_{3}-\mathrm{N} \\
\left(\mathrm{mg} \cdot \mathrm{kg}^{-1}\right)\end{array}$ \\
\hline \multicolumn{7}{|l|}{$\overline{\text { Irrigation (I) }}$} \\
\hline $50 \%$ ETc & 3.5 & 171.1 & 5.6 & 34.7 & 37.8 & 5.7 \\
\hline $75 \%$ ETc & 9.3 & 335.4 & 9.2 & 35.2 & 40.1 & 3.7 \\
\hline $100 \%$ ETc & 7.3 & 304.4 & 6.0 & 40.7 & 38.1 & 9.2 \\
\hline \multicolumn{7}{|l|}{ Nitrogen $(\mathrm{N})$} \\
\hline $0-10 \mathrm{~kg} \cdot \mathrm{ha}^{-1}$ & $2.6 \mathrm{~b}^{\mathrm{z}}$ & $68.9 \mathrm{c}$ & 4.8 & 36.7 & 37.8 & 4.7 \\
\hline $60 \mathrm{~kg} \cdot \mathrm{ha}^{-1}$ & $34.0 \mathrm{~b}$ & $182.3 \mathrm{bc}$ & 6.3 & 37.7 & 41.1 & 4.3 \\
\hline $120 \mathrm{~kg} \cdot \mathrm{ha}^{-1}$ & $4.4 \mathrm{~b}$ & $280.1 \mathrm{~b}$ & 6.9 & 38.6 & 35.5 & 4.8 \\
\hline $180 \mathrm{~kg} \cdot \mathrm{ha}^{-1}$ & $16.4 \mathrm{a}$ & $549.9 \mathrm{a}$ & 9.8 & 34.6 & 40.0 & 10.6 \\
\hline \multicolumn{7}{|l|}{ Interaction } \\
\hline $\mathrm{I} \times \mathrm{N}$ & NS & $*$ & NS & NS & NS & $*$ \\
\hline
\end{tabular}

Soil samples (0- to 13-cm depth) were collected on 27 July 2006 for the 2005-2006 season, 25 June 2007 for the 2006-2007 season, and 12 May 2008 for the 2007-2008 season.

Means within columns followed by different letters are significantly different (least significant difference, $P \leq 0.05)$.

NS $=$ non-significant.

$* P \leq 0.05$.

$\mathrm{ETc}=$ crop evapotranspiration
Nitrogen fertilizer rates did not affect $g_{\mathrm{S}}$ except 191 DAT (Fig. 7).

\section{Discussion}

To introduce artichoke cultural practices into commercial production in water-limited regions of the southern United States, it is important to characterize the impact of irrigation and $\mathrm{N}$ inputs. In this field study, yield, yield components, and the nutritional quality of artichoke in response to three irrigation regimes and four $\mathrm{N}$ fertilizer rates were examined over three seasons, 2005-2006, 2006-2007, and 20072008.

During the first two seasons, the average winter temperatures were $14.0{ }^{\circ} \mathrm{C}$ for the 2005-2006 season and $13.4^{\circ} \mathrm{C}$ for the 2006 2007 season, which were within the range (7 to $29^{\circ} \mathrm{C}$ ) for optimum growth (Schrader and Mayberry, 1997).

Marketable yields increased at $100 \%$ ETc, whereas a $35 \%$ to $20 \%$ of yield reductions occurred at 50\% ETc in the 2005-2006 and the 2006-2007 seasons, respectively (Table 3 ). Consistent with the positive effect on total yield, the number and weight of heads also increased with higher irrigation rates. The yield reduction with the $75 \%$ ETc as compared with $100 \%$ ETc was $12 \%$ and $20 \%$ in the $2005-2006$ and 2006-2007 season, respectively. These results agree with those of Saleh (2003) and Garnica et al. (2004), who reported that deficit irrigation decreased both head number and weight. Others studies also showed a decrease in head number by deficit irrigation (Macua et al., 2005; Pomares et al., 2004). Conversely, increased $\mathrm{N}$ fertilizer did not show any yield improvement in any of the three seasons. Elia and Conversa (2007) reviewed the effect of $\mathrm{N}$ rates on artichoke earliness, yield, and yield components; they highlighted that these responses did not follow a linear trend of $\mathrm{N}$ rates, indicating that responses were dependant on soil fertility, cultivar, cultural practices, and climatic conditions. Studies showed significant impacts on earliness of cv. Orlando with a N
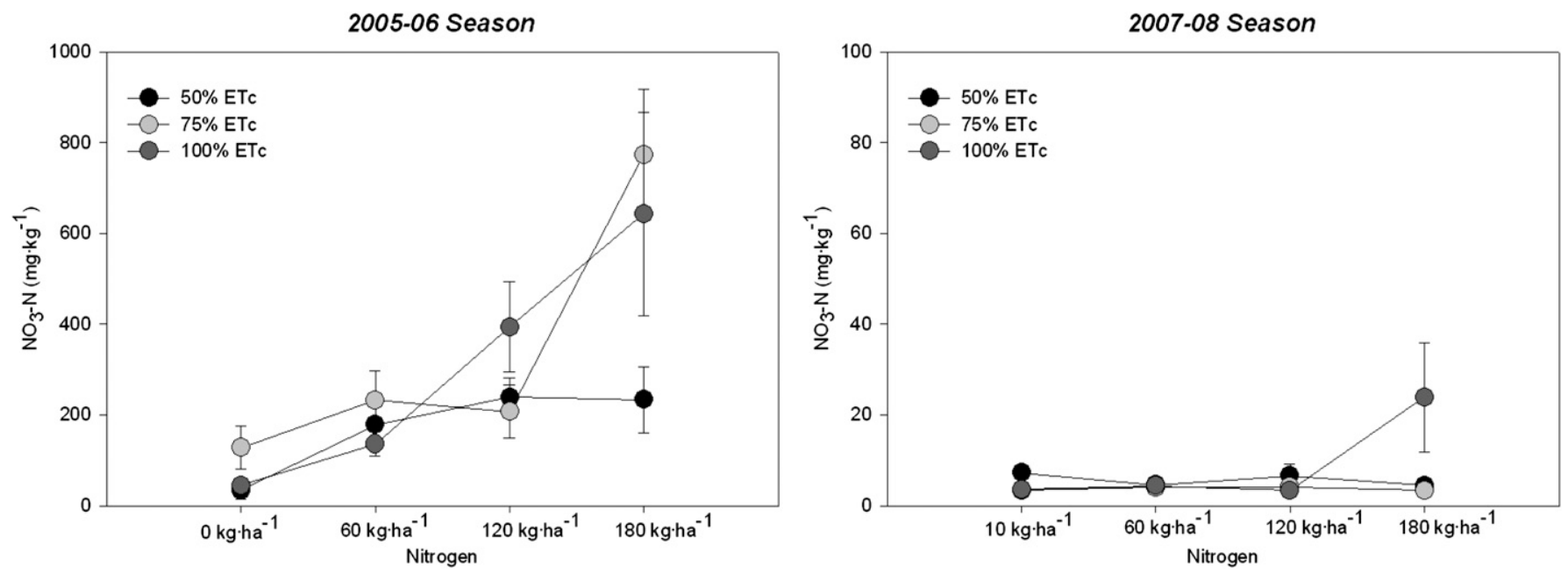

Fig. 4. Effects of irrigation and nitrogen rates on soil $\mathrm{NO}_{3}-\mathrm{N}$ content after harvest for artichoke 'Imperial Star' in the 2005-2006 season (left) and the 2007-2008 season (right). Vertical bars indicate mean \pm se. 
rate of $200 \mathrm{~kg} \cdot \mathrm{ha}^{-1}$ (Foti et al., 2005), improved yield of cvs. Blanca de Tudela and Blanca de Espaňa with 200 to $300 \mathrm{~kg} \cdot \mathrm{ha}^{-1} \mathrm{~N}$ (Ierna et al., 2006; Pomares et al., 1993), or increased head number and weight of vegetative grown cv.
Castellammare with $200 \mathrm{~kg} \cdot \mathrm{ha}^{-1} \mathrm{~N}$ (Paradiso et al., 2007). However, at least three other studies did not show any effect of $\mathrm{N}$ on yield when applied in the range of 0 to $270 \mathrm{~kg} \cdot \mathrm{ha}^{-1}$ on cvs. Imperial Star and Nun 7144 (Pomares et al., 2004), 0 to $400 \mathrm{~kg} \cdot \mathrm{ha}^{-1}$ on 'Orlando' (Foti et al., 2005), and 100 to $215 \mathrm{~kg} \cdot \mathrm{ha}^{-1}$ on romanesco-type cultivars (Saccardo et al., 2005). Our results indicate that acceptable head yields of 'Imperial Star' can be obtained
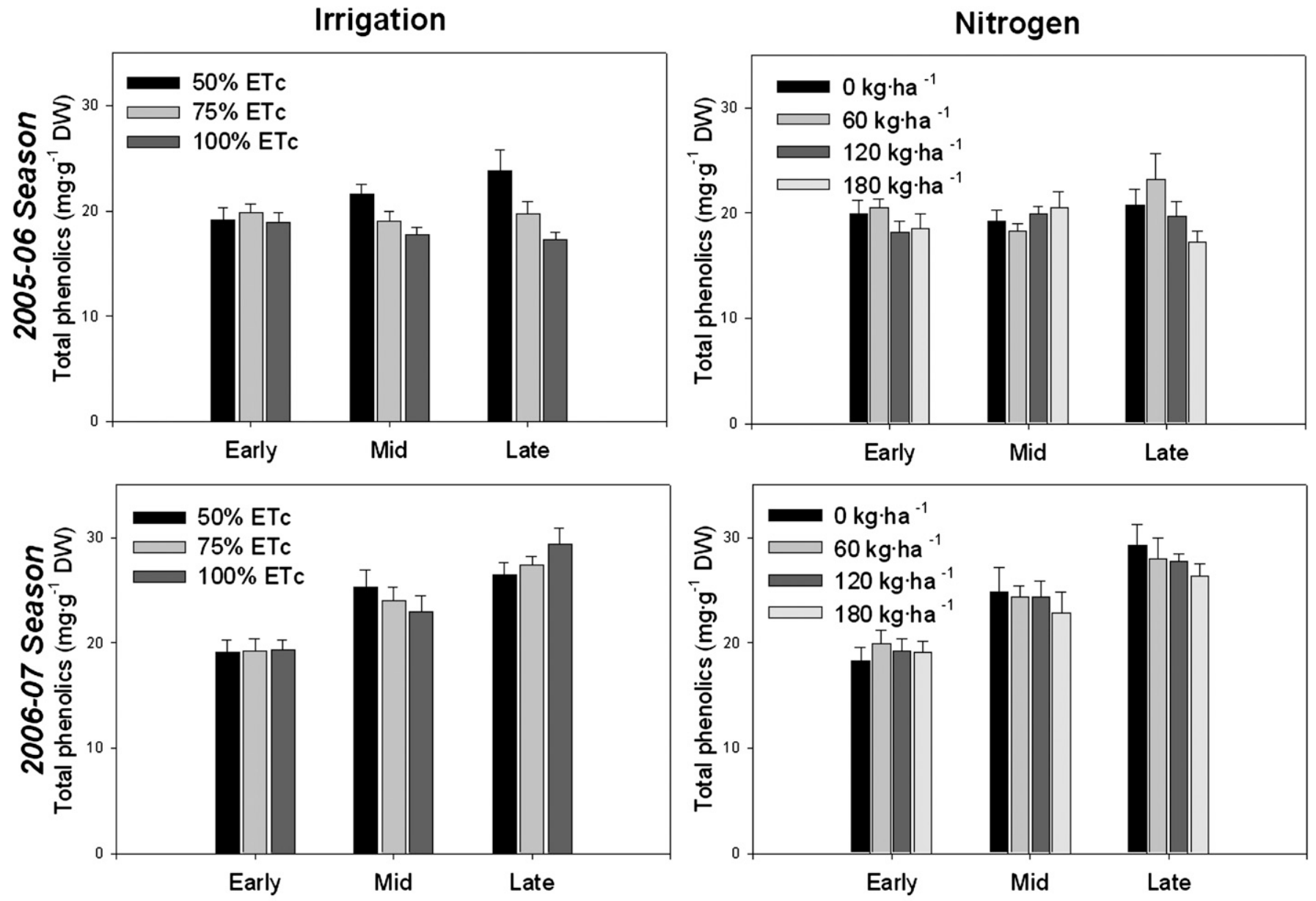

Harvest Season

Harvest Season

Fig. 5. Total phenolic content in artichoke head 'Imperial Star' in response to irrigation (left) and nitrogen (right) rates during harvest (early, mid, and late) in the 2005-2006 season (top) and the 2006-2007 (bottom). Vertical bars indicate mean \pm SE.
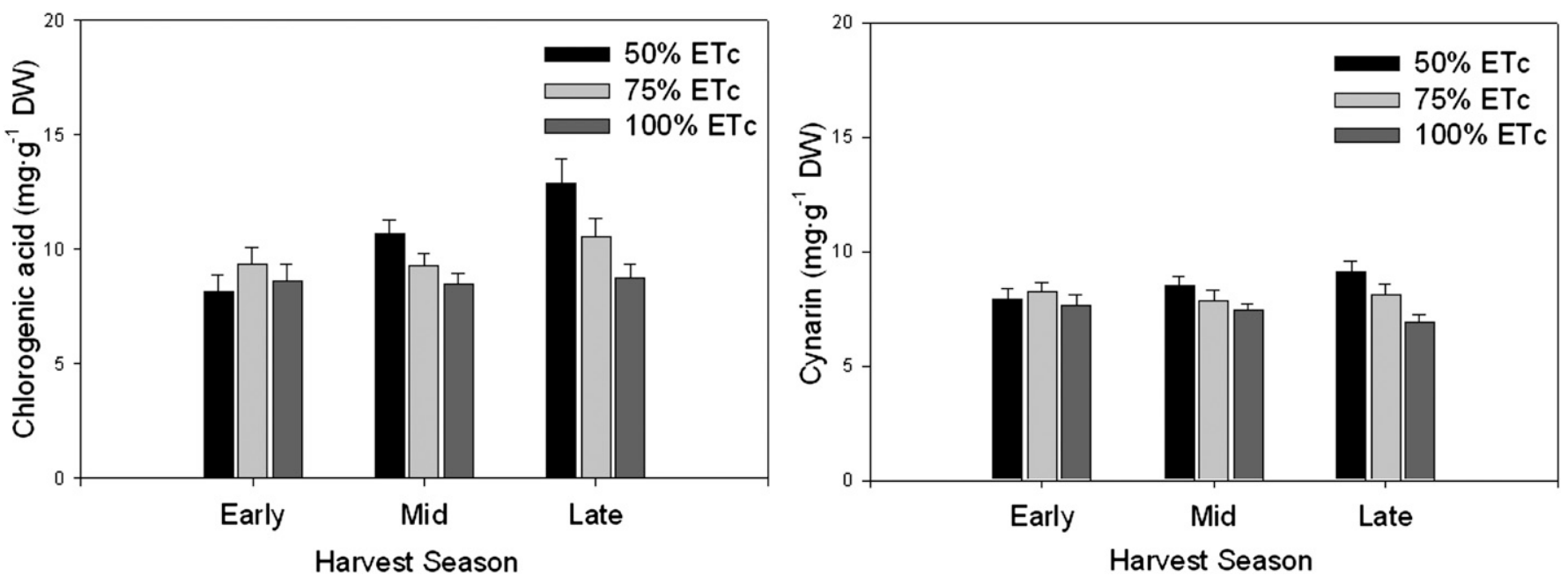

Fig. 6. Chlorogenic acid (left) and cynarin content (right) in artichoke head 'Imperial Star' in response to irrigation rate and harvest time (early, mid, and late) for the 2005-2006 season. Vertical bars indicate mean \pm SE. 

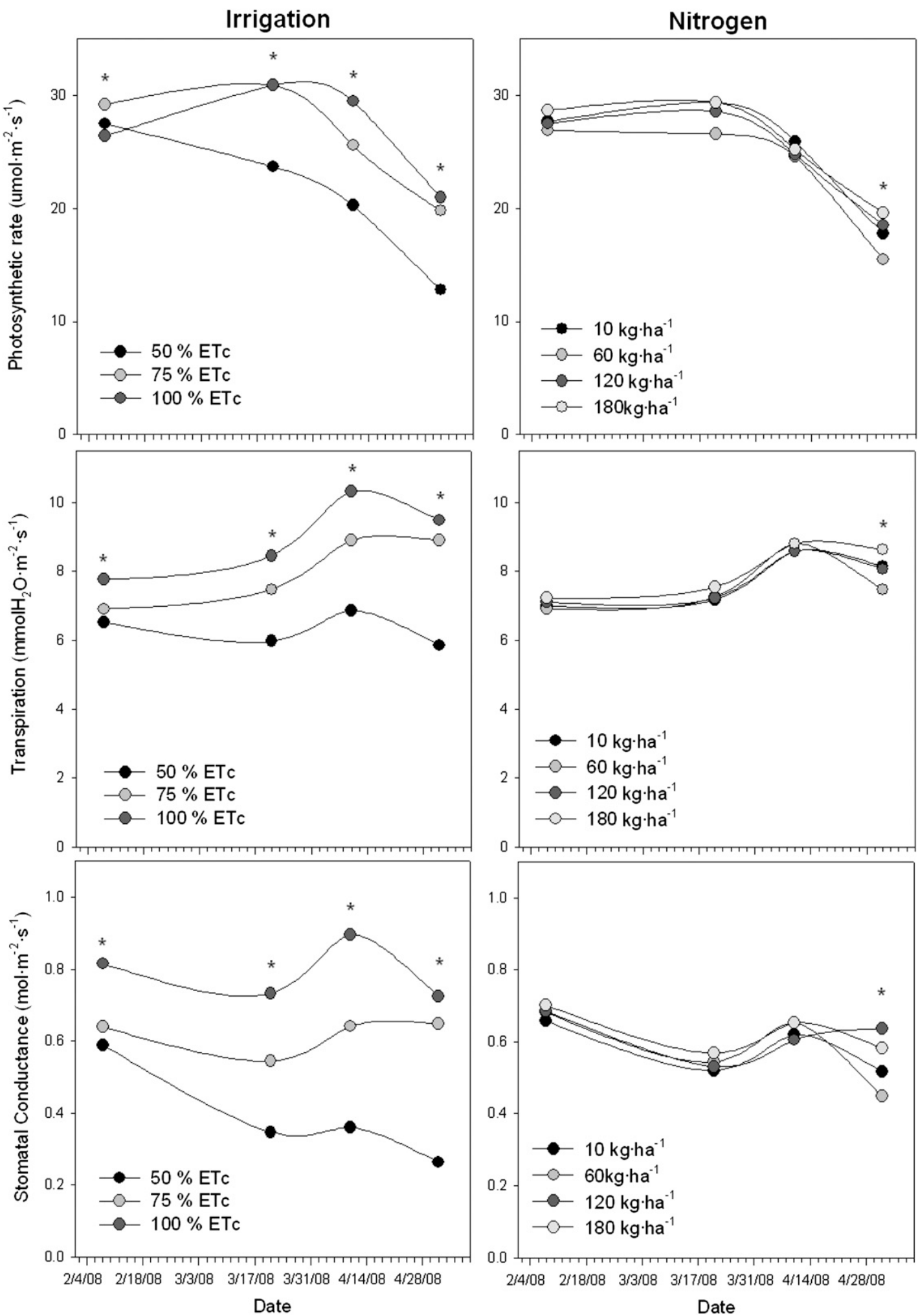

Fig. 7. Plant physiological responses of artichoke 'Imperial Star' in response to irrigation (left) and nitrogen (right) rates, $2007-2008$ season. ${ }^{*} P \leq 0.01$.

with $120 \mathrm{~kg} \cdot \mathrm{ha}^{-1} \mathrm{~N}$ or less based on yield trends obtained from three production cycles under southwest Texas climatic conditions (Table 3).

Head size was less variable in the 20062007 (the majority were medium) as compared with the 2005-2006 season (Fig. 3). This difference in head size distribution between two seasons can be explained by the age of the crop, plant size, and the establishment methods used such as transplants in the 2005-2006 season versus offshoots in the 2006-2007 season. For transplants, a large main or crown head was developed from the main stem followed by seven to 11 medium to small heads produced from lateral branches, whereas for offshoots in the second season (three to five offshoots coming from the main crown), two to four medium heads and small axillary heads per offshoot were produced after the completion of the large main head.

Unmarketable heads or culls (open bracts and tip burn) increased as harvest season progressed in both seasons (Fig. 3). A significantly 
higher proportion of heads with tip burn or atrophy was observed with deficit irrigation or with higher $\mathrm{N}$ rates (120 to $180 \mathrm{~kg} \cdot \mathrm{ha}^{-1}$ ) (data not shown). Several environmental conditions can lead to this physiological head disorder. These include lack of soil phosphorus (P), a high potassium/P ratio, high salinity, and/or $\mathrm{Ca}$ deficiency caused by excess transpiration under high temperatures (Elia and Conversa, 2007; Francois et al., 1991). In addition, our results suggest that plants under either drought stress alone or in combination with high $\mathrm{N}$ rates may also induce tip burn, especially in late harvests.

The larger values of WUE for the 20052006 versus the 2006-2007 season (Table 3) can be attributed to the higher amounts of rainfall, longer crop cycle, and thus higher irrigation frequency in the 2006-2007 season (28 July 2006 to 24 Apr. 2007) as compared with the shorter 2005-2006 season (15 Dec. 2005 to 25 May 2006) (Fig. 1; Table 2). Considering water savings, an annual system would be more efficient than the biennial system, although a relatively higher yield may be expected from the second crop season because of a longer harvesting period (2 Mar. to 24 Apr. 2007 versus 12 Apr. to 25 May 2006) and overall longer crop cycle (Fig. 1). However, weed and pest control management increases in the second year (Mauromicale and Ierna, 1995).

Considering soil $\mathrm{N}$, a relatively high concentration of available $\mathrm{N}\left(\mathrm{NO}_{3}-\mathrm{N}\right)$ at the 0 - to $13-\mathrm{cm}$ depth was present in the field (77.4 $\mathrm{mg} \cdot \mathrm{kg}^{-1}$ ) before planting in 2005 (Table 1). Irrigation rates did not affect $\mathrm{NO}_{3}-\mathrm{N}$ content in all seasons as well as $\mathrm{N}$ treatments, except the 2005-2006 season, when $\mathrm{NO}_{3}-\mathrm{N}$ content at $0-$ to $13-\mathrm{cm}$ depth progressively increased with the rise of $\mathrm{N}$ applications. The interaction was significant during 2005-2006 and 20072008 seasons (Table 4; Fig. 4). The high level of $\mathrm{NO}_{3}-\mathrm{N}$ content evaluated at the end of 2005-2006 season at 0- to 13-cm depth could prove that irrigation treatments were not able to dissolve all $\mathrm{N}$ from the soil surface and to promote $\mathrm{N}$ moving to the deep soil. Note that in this crop cycle, the total rainfall was very low, $68 \mathrm{~mm}$ (Table 2), whereas in the 20062007 season, the abundant rainfall, $288 \mathrm{~mm}$, took part in $\mathrm{N}$ transport to the deep soil as very low $\mathrm{N}$ content was found at 0 - to $13-\mathrm{cm}$ depth. Although this may be beneficial for certain shallow-rooted vegetables such as onion (Halvorson et al., 2008), our results indicated that artichoke plants were not responsive to high $\mathrm{NO}_{3}-\mathrm{N}$ levels at the soil surface. Presumably, active nutrient uptake may be greater at deeper soil layers, where the majority of large roots (taproot and lateral roots) may be present. In fact, the rationale of very low fertilizer $\mathrm{N}$ use of field-grown tomato in California was explained by the poor root system in N-rich soil surfaces (Jackson and Bloom, 1990). Further investigations on root growth dynamics under various establishment systems are required.

Phenolic content in artichoke heads varies with cultivar, growing season, head maturity, storage, and processing (Curadi et al., 2005; Di Venere et al., 2004; Gil-Izquierdo et al., 2001; Llorach et al., 2002; Wang et al., 2003) In this study, the nutritional quality (phenolic content) of artichoke heads was clearly affected by the harvest time. The increase in total phenolic and chlorogenic acid content (2005-2006 season) by deficit irrigation was more pronounced as the harvesting season progressed (Figs. 5 and 6). Wang et al. (2003) also reported higher amounts of phenolics in artichoke mature heads of 'Imperial Star' and 'Green Globe' harvested in October compared with those in September. Phenolic content in artichoke heads also may increase with plant maturity, as shown in other vegetables (Deepa et al., 2007; Pandjaitan et al., 2005). Indeed, it has been proposed that plant environmental stresses such as cold, heat, water deficit, and/or flooding exert a considerable influence on the levels of plant secondary metabolites such as polyphenolics and phenylpropanoids (Dixon and Paiva, 1995; Kirakosyan et al., 2004; Oh and Rajashekar, 2009). Therefore, the increase in phenolic content of artichoke heads by deficit irrigation may be a plant defense response against drought stress as shown in other vegetables (English-Loeb et al., 1997). High precipitation during 2006-2007 may have reduced the influence of differential irrigation treatments (Fig. 1; Table 2). Nevertheless, total phenolics were similar except at the late harvest (Fig. 5). Although there are findings indicating that higher $\mathrm{N}$ application rates inversely affected phenolic content in artichoke leaves (Eich et al., 2005), our study showed a decline of total phenolics only at $180 \mathrm{~kg} \cdot \mathrm{ha}^{-1} \mathrm{~N}$ for the late harvests (Fig. 5).

Marketable yields in the 2007-2008 season were significantly increased at $100 \%$ ETc, whereas $7 \%$ and $30 \%$ yield reductions occurred at $75 \%$ and $50 \%$ ETc, respectively (Table 3). As we observed in the 2005-2006 season, total yield at $100 \%$ ETc was consistent with the increase on both number and weight of heads. The proportion for marketable heads for 2007-2008 season was similar to the 20052006 season but showed a higher proportion of larger and heavier heads at $100 \%$ ETc. Although this study was not designed to compare a mulching system (bare soil versus plasticulture), certainly plastic mulch application increased WUE by two- to threefold compared with bare soil as measured in the 2005-2006 and the 2006-2007 seasons (Table 3). Overall, at $100 \%$ ETc rates, plastic mulch application in the 2007-2008 season effectively saved $56 \%$ and $61 \%$ of irrigation water when compared with the two previous seasons. Therefore, plasticulture appears to be a promising management tool to improve crop performance and water saving when artichokes are grown as annuals. Although no significant effect of $\mathrm{N}$ rates on yield, head number, or head weight were measured in the 2007-2008 season (Table 3), residual soil $\mathrm{NH}_{4}-\mathrm{N}$ was apparently higher and $\mathrm{NO}_{3}-\mathrm{N}$ lower than the other two seasons (Table 4). Further investigations addressing $\mathrm{N}$ balance are required to understand if $\mathrm{N}$ applied through a fertigation system using the plasticulture technology can be more efficiently used by artichoke plants.

Plant physiological responses $\left(\mathrm{A}_{\mathrm{CO} 2}, \mathrm{E}\right.$, and $\left.g_{\mathrm{S}}\right)$ measured in the 2007-2008 season correlated well with the irrigation treatments. When plants are exposed to drought stress, stomata closed progressively, decreasing $g_{s}$, with a parallel reduction in both $\mathrm{E}$ and $\mathrm{A}_{\mathrm{CO} 2}$ (Tezara et al., 1999). The physiological responses to differential irrigation rates in our study indicate that artichoke plants subjected to deficit irrigation $(50 \%$ ETc) exhibited a significant drought stress throughout the season, thus reducing vegetative growth (not shown) and lowering yields. Our results showed no apparent effects of $\mathrm{N}$ rates on these physiological responses during late development (Fig. 7).

In conclusion, irrigation was more effective than $\mathrm{N}$ management to optimize artichoke yield. The yield reduction by deficit irrigation was associated with a decrease in both head number and weight. We estimate that $\approx 700$ $\mathrm{mm}$ (for a bare soil system) and $\approx 350 \mathrm{~mm}$ (plasticulture system) of water inputs and 120 $\mathrm{kg} \cdot \mathrm{ha}^{-1}$ or less of $\mathrm{N}$ appears sufficient to obtain high marketable yields under our environmental conditions. However, growers need to control soil available $\mathrm{N}$ before planting so that rates can be adjusted accordingly. In terms of nutritional quality (phenolic content), harvest time appeared to have the largest effect followed by deficit irrigation as measured in one season. Conversely, using this strategy to enhance phenolic content on artichoke heads will significantly reduce marketable yields and head size.

\section{Literature Cited}

Alamanni, M.C. and M. Cossu. 2003. Antioxidant activity of the extracts of the edible part of artichoke (Cynara scolymus L. var. Spinoso Sardo). Ital. J. Food Sci. 15:187-195.

Basnizky, Y. 1985. Cynara scolymus, p. 391-399. In: Halevy, A.H. (ed.). Handbook of flowering. 2nd Ed. CRC Press, Boca Raton, FL.

Boari, F., V. Cantore, E. De Palma, and P. Rubino. 2000. Evapotranspiration trend in seed propagated artichoke, [Cynara cardunculus L. var. scolymus (L.) Fiori], in southern Italy. Acta Hort. 537:511-518.

Brutti, C.B., E.J. Rubio, B.E. Llorente, and N.M. Apostolo. 2002. Artichoke leaf morphology and surface features in different micropropagation stages. Biol. Plant. 45:197-204.

Curadi, M., P. Picciarelli, R. Lorenzi, A. Graifenberg, and N. Ceccarelli. 2005. Antioxidant activity and phenolic compounds in the edible parts of early and late Italian artichoke (Cynara scolymus L.) varieties. Ital. J. Food Sci. 17:33-44.

Deepa, N., C. Kaur, B. Beorge, B. Singh, and H.C. Kapoor. 2007. Antioxidant constituents in some sweet pepper (Capsicum annuит L.) genotypes during maturity. Food Sci. Tech. 40:121-129.

Di Venere, D., L. Sergio, A. Cardinali, V. Linsalata, M. Pieralice, L. Massignan, and R. Lovino. 2004. Biochemical changes during modified atmosphere storage of artichoke heads. Acta Hort. 660:587592.

Dixon, R.A. and N. Paiva. 1995. Stress-induced phenylpropanoid metabolism. Plant Cell 7: 1085-1097.

Eich, J., C. Baier, M. Grun, D. Wagenbreth, and R. Zimmermann. 2005. Artichoke leaves used for herbal drug production: Influence of nitrogen fertilization on yield and on pharmaceutical quality. Acta Hort. 681:545-554. 
Elia, A. and G. Conversa. 2007. Mineral nutrition aspects in artichoke growing. Acta Hort. 730:239-249.

English-Loeb, G., M.J. Stout, and S.S. Duffey. 1997. Drought stress in tomatoes: Changes in plant chemistry and potential nonlinear consequences for insect herbivores. Oikos 79:456-468.

Food and Agriculture Organization of the United Nations. 1998. Crop evapotranspiration-Guidelines for computing crop water requirementsFAO Irrigation and Drainage Paper 56. 7 Mar. 2010. <http://www.fao.org/docrep/x0490e/ x0490e00.HTM>.

Foti, S., G. Mauromicale, and A. Ierna. 2005. Response of seed-grown globe artichoke to different levels of nitrogen fertilization and water supplies. Acta Hort. 681:237-242.

Francois, L.E., T.J. Donovan, and E.V. Maas. 1991. Calcium deficiency of artichoke buds in relation to salinity. HortScience 26:549-553.

Garnica, J., J.I. Macua, I. Lahoz, and A. Malumbres. 2004. Influence of irrigation in the production and industrial quality of artichoke in Navarra. Acta Hort. 660:359-364.

Gil-Izquierdo, A., M.I. Gil, M.A. Conesa, and F. Ferreres. 2001. The effect of storage temperature on vitamin $\mathrm{C}$ and phenolics content of artichoke (Cynara scolymus L.) heads. Innov. Food Sci. Emerg. Technol. 2:199-202.

Halvorsen, B.L., M.H. Carlsen, K.M. Phillips, S.K. Bøhn, K. Holte, D.R. Jacobs, Jr. and R. Blomhoff. 2006. Content of redox-active compounds (i.e. antioxidants) in foods consumed in the United States. Amer. J. Clin. Nutr. 84:95-135.

Halvorson, A.D., M.E. Bartolo, C.A. Reule, and A. Berrada. 2008. Nitrogen effects on onion yield under drip and furrow irrigation. Agron. J. 100: 1062-1069.

Ierna, A., G. Mauromicale, and P. Licandro. 2006. Yield and harvest time of globe artichoke in relation to nitrogen and phosphorous fertilization. Acta Hort. 700:115-120.

Jackson, L.E. and A.J. Bloom. 1990. Root distribution in relation to soil nitrogen availability in field-grown tomatoes. Plant Soil 128:115-126.

Kirakosyan, A., P. Kaufman, S. Warber, S. Zick, K. Aaronson, S. Bolling, and S.C. Chang. 2004. Applied environmental stresses to enhance the levels of polyphenolics in leaves of hawthorn plants. Physiol. Plant. 121:182-186.

Ko, J., G. Piccinni, T. Marek, and T. Howell. 2009. Determination of growth-stage-specific crop coefficients $(\mathrm{Kc})$ of cotton and wheat. Agr. Water Mgt. 96:1691-1697.

Llorach, R., J.C. Espin, F.A. Tomás-Barberán, and F. Ferreres. 2002. Artichoke (Cynara scolymus L.) byproducts as a potential source of healthpromoting antioxidant phenolics. J. Agr. Food Chem. 50:3458-3464.

Macua, J.I., I. Lahoz, and J. Garnica. 2005. The influence of irrigation water quantities on the production and quality of the 'Blanca de Tudela’ artichoke. Acta Hort. 681:257-262.

Mansour, M., R. Mougou, and A. Mougou. 2005. Effect of several modes of irrigation and fertigation on artichoke crop. Acta Hort. 681:127134.

Mauromicale, G. and A. Ierna. 1995. Effects of gibberellic acid and sowing date on harvest time and yields of seed grown globe artichoke (Cynara scolymus L.). Agronomie 15:527-538.

Miccadei, S., D. Di Venere, A. Cardinali, F. Romano, A. Durazzo, M.S. Foddai, R. Fraioli, S. Mobarhan, and G. Maiani. 2008. Antioxidative and apoptotic properties of polyphenolic extracts from edible part of artichoke (Cynara scolymus L.) on cultured rat hepatocytes and on human hepatoma cells. Nutr. Cancer 60:276-283.

Oh, M.-M. and C.B. Rajashekar. 2009. Antioxidant content of edible sprouts: Effects of environmental shocks. J. Sci. Food Agr. 89:2221-2227.

Pandjaitan, N., L.R. Howard, T. Morelock, and M.I. Gil. 2005. Antioxidant capacity and phenolic content of spinach as affected by genetics and maturation. J. Agr. Food Chem. 53:8618-8623.

Paradiso, R., B. Cuocolo, and S. De Pascale. 2007. Gibberellic acid and nitrogen rate affect yield and quality of artichoke. Acta Hort. 730:211-216.

Pomares, F., C. Baixauli, J.M. Aguilar, A. Giner, F. Tarazona, J. Gómez, and R. Albiach. 2004. Effects of water and nitrogen fertilization on seed-grown globe artichoke. Acta Hort. 660:303-309.

Pomares, F., M. Tarazona, M. Estela, R. Bartual, and L. Arciniaga. 1993. Response of globe artichoke to nitrogen, phosphorous and potassium fertilizer. Agrochimica 12:111-121.

Rincón, L., A. Pérez, C. Pellicer, A. Abadia, and J. Sáez. 2007. Nutrient uptake by artichoke. Acta Hort. 730:287-292.

Romani, A., P. Pinelli, C. Cantini, A. Cimato, and D. Heimler. 2006. Characterization of Violetto di Toscana, a typical Italian variety of artichoke (Cynara scolymus L.). Food Chem. 95:221-225.
Ryder, E.J., N.E. De Vos, and M.A. Bari. 1983. The globe artichoke (Cynara scolymus L.). HortScience 18:646-653.

Saccardo, F., O. Temperini, G. Colla, and A. Graifenberg. 2005. Impact of conventional and low-input farming system on yield quality of artichoke cultivars. Acta Hort. 681:233-236.

Saleh, S. 2003. Physiological responses of artichoke plants to irrigation and fertilization under special recognition of salinity. $\mathrm{PhD}$ thesis, Technische Universität München. 7 Mar. 2010.

Schrader, W.L. and K.S. Mayberry. 1997. Artichoke production in California. Univ. of California. Vegetable Research and Information Center. Division of Agriculture and Resources. Vegetables Production Series. Publication 7221.

Schütz, K., D. Kammerer, R. Carle, and A. Schieber. 2004. Identification and quantification of caffeoylquinic acids and flavonoids from artichoke (Cynara scolymus L.) heads, juice, and pomace by HPLC-DAD-ESI/MS. J. Agr. Food Chem. 52:4090-4096.

Sims, W.L., V.E. Rubatzky, R.H. Sciaroni, and W.H. Lange. 1977. Growing globe artichokes in California. University of California Vegetable Research and Information Center.

Singleton, V.L. and J.A. Rossi, Jr. 1965. Colorimetry of total phenolics with phosphomolybdicphosphotungstic acid reagents. Amer. J. Enol. Viticult. 16:144-158.

Tesi, R., P. Lombardi, and A. Lenzi. 2004. Nursery production of rooted offshoots of globe artichoke (Cynara Scolymus L.). Acta Hort. 660: 399-403.

Tezara, W., V.J. Mitchell, S.D. Driscoll, and D.W. Lawlor. 1999. Water stress inhibits plant photosynthesis by decreasing coupling factor and ATP. Nature 401:914-917.

United States Department of Agriculture. 2004. 2002 Census of Agriculture, summary and state data. National Agricultural Statistics Service. 7 Mar. 2010. <http://www.agcensus.usda.gov/ Publications/2002/USVolume104.pdf $>$.

Vinson, J.A., Y.A. Dabbagh, M.M. Serry, and J. Jang. 1995. Plant flavonoids, especially tea flavonols, are powerful antioxidants using an in vitro oxidation model for heart disease. J. Agr. Food Chem. 43:2798-2799.

Wang, M., J.E. Simon, I.F. Aviles, K. He, Q.Y. Zheng, and Y. Tadmor. 2003. Analysis of antioxidative phenolic compounds in artichoke (Cynara scolymus L.). J. Agr. Food Chem. 51:601-608. 